\title{
Incursion Into Wendigo Territory
}

\author{
Jackson Eflin, Ball Sate University
}

This article explores modern urban legends that appropriate the idea of the Wendigo, a spirit from various Native American tribal legends. These urban legends are informed by a cultural guilt of the dispossession of Native American territories, but the victory of monster over protagonist demonstrates the futility of these attempts to comprehend histories of atrocities.

\section{"There are places that can take your memory away." - Jack Wawastases}

Much has been taken from the indigenous peoples of the Americas: land, history, identity, name, and voice. The colonization of the Americas took place on both a physical and cultural level, and so, in the end, even myths were colonized. But as the line of the Frontier was pushed westward, a curious legend slipped through the cracks, and the attempts to hunt down and capture this legend go on today. Called Wendigo, Windigo, Whitiko, Atchen, Chenoo, or a host of other names by different peoples, the legend of the cannibal spirit who brings snow and hunger in its cloven gait was just as terrifying to settlers as it was to natives, and so attempts to settle it persist. The people and the places that created the Wendigo are colonized now, mapped and measured, a thousand cultures swallowed up by trading posts and concrete roads. But the memory of the Wendigo and all it represents haunts the collective unconscious of America, a howling reminder of colonial dispossession. The use of the Wendigo in modern urban legends shows how America is wrestling with this guilt. If we accept Cynthia Landrum's assertion of "urban legends represented as warnings or cautionary tales" (266), then these narratives can be seen as cautionary tales against forgetting the history of the territories America has colonized.

Understanding the Wendigo's place in both native and colonial mythology gives a perspective into the larger conflict it represents in the collective unconscious of America as a whole. This paper will examine the original myths of the Wendigo and how their use in the lore of modern urban legends circulated on anonymous internet forums represents an ongoing struggle over a stretch of cultural territory by deconstructing the presentation of Wendigos in these stories and how the intentional presentation of the monster reflects representations of Native Americans.

Before proceeding, it is vital to explore a bit of where the Wendigo myth comes from. This is a thorny issue, as these stories are in many ways not mine to tell. Deirdre Keenan, exploring the difficulties of representing the overlap of her Irish ancestral history and the history of Native Americans asks, "[H]ow can I represent indigenous voices rather than 'voices that have been ventriloquized' out of an 'imperialist nostalgia?"' (186). This essay comes from a similar place as Keenan's, written by a colonizer, not a native, and thus these examinations of traditional myths should not be seen as authoritative recitations but as 
reflections that show a shape of history, but not the only shape.

Appearing in myths from the Great Lakes and regions north and west, told by the Cree, Algonquin, Ojibwe, and Mi'kmaq peoples, ${ }^{1}$ amongst others, the nature of the Wendigo varies wildly, but the common threads are of cold and hunger. In the stories, a tribe's village will often be having trouble feeding itself due to the scarcity of game or other machinations of a Wendigo in the area. The Wendigo will use a wide repertoire of tricks, from vanishing the meat off of still-living game to mimicking the face or voice of a hunter, to lure prey away from home, where it will eat or possess them, causing them to "go Wendigo."2 Usually the Wendigo is defeated by destroying its icy heart. In these stories, the death of the Wendigo signals the end of starvation, and in some cases the end of winter and the coming of summer.

Howard Norman argues in his introduction to Where the Chill Came From: Cree Wendigo Tales and Journeys, that the Wendigo upset the "old agreement" of the hunt, that humans hunt and animals are hunted. As part of the arrangement, the Cree allow hunting ground to rest and replenish and they tell stories about the slain animals to honor them. The Wendigo, however, obstructs hunting, or hunts in the village, where no one is supposed to be prey. Wendigos use their tricks to isolate a person, a manifestation of a very real fear of losing your way while hunting, and the danger of a lost hunting party turning to cannibalism if unsuccessful. This taboo against cannibalism is one of the metaphors the Wendigo makes material.

D. H. Turner, in "Wendigo Mythology and the Analysis of Cree Social Structure," relates a myth in which a man and his son eat their grandchild and wife, respectively. This act of devouring incorporates one into the other, which Turner explores as an upsetting of the traditional method of incorporation of others into the family through marriage. He highlights this by referring to the characters as "Grandfather/Grandson" and "Father/Mother," showing how the consumed still have presence in the consumer. He explains that Cree tribes space themselves across the landscape to facilitate proper social relations. The transgressing of boundaries, both physical and genealogical, disrupts the natural order of things.

In both of these interpretations, the Wendigo is responsible for the radical upsetting of properly defined lines, both in landscape and social structure. The Wendigo carries the fear of consumption in two ways, both the simple fear of being eaten but also the fear of "going Wendigo" yourself, being possessed or infected, the Wendigo getting into you. Either way, someone is where they do not belong, and this trespass is terrifying.

The Wendigo's connection to territory goes back to when colonists first encountered it. The writings of Jesuit Minister and Evangelist Paul Le Jeune, which contain the earliest known reference to the Wendigo, also contain a territorial theme:

...this Devilish Woman ${ }^{3}$ added that [the Wendigo] had eaten some Attikamegouekhin - these are the tribes that live north of the River which is called the Three Rivers, - and that he would eat a great many more of them if he were not called elsewhere. But that Atchen, ${ }^{4}$ (a sort of Werewolf), would come in his place to devour them, if they made a village, as they had decided

1. It should be noted that the lines between these cultures are somewhat fuzzy, and the way they are defined comes from both native and Western categorizations. Originality of the Wendigo myth thus can vary wildly depending on the source of the story.

2. The Wendigo is consistently described as possessing, as opposed to the more apt infecting. This repeated use of possession to describe "going Wendigo" suggests an unconscious connection between the Wendigo and ownership.

3. A religious official doing trance work to facilitate glossolalia. Le Jeune reinterprets this as demonic possession.

4. "Atchen" or "Chenoo" is generally accepted to be the Montagnais-Naskapi word for the Wendigo, or at least for a being of such similar mythology that the differences are primarily linguistic. 
to do; that he would come to get them, even up to the French Fort; that he would slaughter the French themselves. (Le Jeune 7)

The wording, "even up to the French fort...the French themselves" has a subtle implication of the French being on some higher order. Something about their French-ness, their civilized-ness, apparently makes their space better, gives them some inherent guard against the evils of the wild. This establishment of the "better space" is an attempt to reassert colonial power by relegating native space as being in some nebulous way inferior, more prone to predation. The description of the Atchen as "some kind of werewolf" is also a colonial move. This changes the threat from a native one, and thus beyond the territory of colonial mythology, to something within European understanding. While there are similarities between the Wendigo and the werewolf, both animalistic anthropophages who were once human, the werewolf can become human again, whereas once you "go Wendigo" you never go back. ${ }^{5}$ This subtle move to put down stakes in this unfamiliar territory shows the conqueror's response to the unknown, to redefine or jettison to a safe distance. Even if it isn't understood, it is at least pushed to the periphery.

Over the next four hundred years, the Wendigo would stalk the edges of American discourse. For native writers it was often used as a metaphorical device, as seen in Tracks or Solar Storms. In Tracks: A Novel by Ojibwe author Louise Erdrich, the narrator contextualizes the maddening depression brought on by deaths from plague by saying that "We had gone half Windigo (6),"6 that is, gone half mad from the extremes of loss and winter. The narrator's abusive mother in Linda Hogan's Solar Storms is said to be possessed by the Wendigo. On the other hand, for colonial writers it was a fertile ground for mining boogeymen. August Delerth added it to the canon of the Cthulhu Mythos in Ithaqua. In Pet Semetery by Stephen King, the necromantic properties of the eponymous cemetery are attributed to a Wendigo having soured the ground. All of these references draw on the power of a symbol with deep cultural roots, though in Hogan's and Erdrich's cases the invocation of the Wendigo integrates the narratorial present with their cultures' pasts, while Delerth's and King's invocations attempt to connect their characters' troubles to a longer narrative that breaches cultural boundaries. The use in Ithaqua and Pet Semetary can be seen as what Boyd and Thrush call "the settler society's attempts to make a usable history out of its colonial past" (xxiii). This colonial past is full of ghosts that haunt the colonized present, and the native-born spirit that haunts the Americans around King's cemetery is just another example, the anxieties of colonial guilt refusing to stay buried.

This brings the narrative to the modern-day, where the Wendigo is quite fashionable on the imageboard. Since the story nicknamed "Cabin Fever," posted in 2012, started the recent Wendigo fad, over fifty Wendigo-related stories have become creepypastas. Such stories are posted on 4chan, a largely anonymous forum where posts are usually deleted after a few days of inactivity. Thus good stories are copied down as text documents, which can be easily copied and pasted into a new thread. This "copy and paste" method of story sharing became abbreviated to copypasta, the subset of horror stories being referred to

Notes

5. In all fairness to Le Jeune, explaining the Wendigo is rather difficult. It acts a bit like a Werewolf in its anthropophagia and living in the woods, but its supernatural powers make it seem like a sorcerer. For this paper I will use a hauntological lens, addressing it like a ghost in order to examine a cultural role it plays. Technically the Wendigo is a type of Manitou, an Algonquin word that refers to a variety of spirits.

6. The phrase "going Wendigo" or "to go Wendigo" is a recurring phrase that indicates a person has been fully possessed and overtaken by the cannibalistic mania of the Wendigo. 
as creepypasta. A majority of the Wendigo creepypastas follow the same format, with young adults being hunted by some thing in the woods, and so repetitious is the formula that new stories are often met with accusations of unoriginality. I'll be looking at two of these stories closely, to show how they reflect this pattern of cultural colonization. While there are a variety to choose from, these two have clear and unambiguous links to the Wendigo, as opposed to merely a shade bearing its shape without realizing it is doing so.

These stories are valuable to examine because they are a snapshot of modern American culture. The Wendigo appears in many other stories, both on 4chan and elsewhere, but the stories examined here have the added advantage of being anonymous. Unattached to faces and names, each individual post must be read on its own merits, with no history to distort them. And yet despite being free of history, the stories keep circling back to aspects of history that haunt the cultures that created them. The inescapability of the Wendigo, even in a space beyond identity, shows how deeply its teeth are dug into the culture of America, thus the stories repeat with only small changes, always trying to grasp the shape of a history that refuses to stay quiet.

The story that started the trend, "Cabin Fever," was posted some time in summer 2012. The narrator, "a city kid from Chicago," goes camping with cousins on their family's land in Alabama. During the first day of camping, the teenagers run into a neighbor, Tanner, who joins them. Between them, there are five girls and six guys. A typical camping day goes by, and Tanner pops home to ask permission to stay the night, two campers going with him as an honor guard. An hour later they come running back into the cabin, followed by everyone else, reporting strange goings on in the woods: someone following them on the path, spasming, back turned the whole time. They assume it's some mischievous rednecks until one of the cousins begins to panic, "going on about how he went to school with a native kid that was telling him about the goat man." He is chastised for worrying everyone, but continues, "going on and on about how it's the goat man 'and how we're in his woods."' The narrator interrupts the narrative for a moment to explain that at the time he had never heard of the Goatman:

but then a couple years ago ${ }^{8}$ the year before I graduated from college I had a Menom $^{9}$ for a roommate and I ended up asking him about it. And to sum it up, it's basically a fucking man with the head of a goat and he can shape shift and he gets among groups of people to terrorize them. It's also supposed to be kind of like the Wendigo and it's bad mojo to even talk about it and even worse if you see it.

They eventually calm down, cooking three sausage packs, each with four sausages in them. An argument breaks out when the narrator is accused of taking two, which he denies, having given one to everyone specifically.

About then it dawns on them what is wrong, just as a camper who had accompanied Tanner starts screaming for everyone to get out. Everyone flees the cabin and, upon counting, realizes that now there are only eleven people where there had been twelve. The narrator 
realizes that, with so many people who all knew only a few others in the group, it had been easy for the Goatman to slip in. The story continues in this vein for quite some time, juggling numbers so that it is easy to lose track of how many people should be there.

Eventually Tanner darts home for a gun. Upon returning, he and the narrator realize the Goatman slipped in and out again, and the narrator starts to panic: "But at least I feel better because we can be American and shoot the fuck out of whatever it is if it comes back." Terrifying sounds of the Goatman trying to get in last through the night, sounding like an animal failing to imitate human speech, until a few shots are fired into the darkness, driving it off. Screeching noises persist, echoing in the woods.

Tanner stays awake through the night and realizes that at some point some one, or some thing, has slipped into the cabin. Not wanting to scare anyone he says nothing, watching as it pretends to sleep, standing up occasionally in the dark to jitter and lie down again. They hurry home the next morning and, arriving at the house, the Goatman gives Tanner a deadeye stare, lags to the back of the group, and then vanishes into the forest.

The Goatman in this narrative explores the classic idea of haunting that can be described as the "present absence." Avery Gordon wrestles with this idea, exploring how absences in narrative, history, and memory can only be reconstructed by examining the shape of the gaps they leave behind. She differentiates the ghost from haunting, defining haunting as "that which appears to not be there, a seething presence, acting on and often meddling with taken-for-granted realities, the ghost is just the sign, or empirical evidence if you like, that tells you that a haunting is taking place" (Gordon 8). The ghost, to Gordon, is the marker of a gap in history, culture, or memory, "cajoling us to reconsider" (6). This applies significantly to this narrative, which is riddled with absent presences.

One of the absent presences is the smell that always seems to signal the coming of the Goatman. At the start it smells "like ozone," but towards the end of the narrative it evolves into "an actual nasty gross blood smell, like cooking blood and singed hair." The smell comes and goes, but at one point the smell just vanishes. The narrator tells us "usually smells fade away or get less. It just literally was there one second and then not the second." Not only does this underline the supernatural nature of the threat being faced, but it also calls attention to absences. Later, when the Goatman, in the form of one of the campers, is writhing, as though she were laughing, but silently, causes the narrator to realize that the woods are totally devoid of any sound, no birds or squirrels to be heard. Again, the actions of the spectre draw attention to absences, and while this absence is literal, others are less so.

The Goatman is never given a form or a voice, and is only ever able to imitate, only able to interact with the world in the form of an intruder. The native figure never speaks with its own words; instead the words of the invader are put into its mouth, and it is ventriloquized like a puppet. Kathryn Shanley explores this idea of ventriloquism as an unvoicing of native peoples, their stories told by people claiming to speak with their voice. The native voice here is removed. Shanley states, "[T]he exclusion of Indian voices perpetuates the idea that non-Indians can speak for Indians better than Indians can speak for themselves" (688). The unvoicing of natives removes the ability to tell their own story, and thus define themselves. This puts the native in a spectral position, present but unable to affect change, intangible.

When the Wendigo is given voice, even the voice is spectral as it cannot be defined. In many creepypastas, there will be a moment where the author will try to describe the noises, always failing to properly articulate them, defining them as "not human, not like any animal ever heard." For the author of "Cabin Fever," the creatures trying to imitate human speech sound "like those YouTube cats and dogs whose owners teach them how to "talk." 
The narrator describes the way all people of all languages have a certain cadence, and that this is like none of them.

The Goatman's not-quite-human behavior and inability to quite mimic human speech plays on the literary device of the uncanny, that which reveals the strangeness in the familiar. Gesa Mackenthun states that "the literary mode of the uncanny fulfils a memory function; it brings to light forgotten or subjugated knowledges. The greatest uncanny effect is when a 'Rememory' (to borrow Morrison's term $)^{10}$ invades the family home" (98). It is the subjugated knowledge being pushed to the forefront that is more terrifying than the Goatman's physical trespass. The characters put a great deal of effort into keeping the Wendigo out of the family's home, despite its seeming ability to come and go freely. After all, according to one of the panicking campers, these are "his woods." The fear of these buried memories resurging to recolonize territory from which they had been pushed shines through here in the Goatman's almost casual ability to reinvade spaces thought entirely safe. The Goatman literally unsettles, both by being a fearful presence and by uprooting the settler's assumptions that the settled land is a controlled property, as opposed to an unwilling hostage. The unvoiced monster brings to light the voiceless victims, silenced so that their presence may be ignored or forgotten.

Another creepypasta dealing with issues of the control over native presence and space, "Territories," was posted on July 23, 2013. Posted along with the opening text was a map pointing to a point in the deep Canadian wilderness west of the Great Slave Lake. The narrator is in the Canadian Army, $3^{\text {rd }}$ Canadian Division, his traveling companion a reservation-born Algonquin named Pannoowau. They drive off road for a few days and eventually make camp a few miles from their car. In the night they are disturbed by something moving around their campground.

Pannoowau assists the narrator in trying to track whatever thing is stalking their camp, leaving "kind of 'morphed' human footprint[s]." At one point they hear a terrible shriek, "like the sound a pig makes when it's being butchered while still alive." Pannoowau declares that "Bad Spirits walk among us," which the narrator disbelieves. Eventually Pannoowau convinces him to return to camp. However, their trail back vanishes, and Pannoowau, not wanting to worry the narrator, says nothing. This is when a critical portion of the narrative happens. Pannoowau is explaining his methods to get unlost:

"I figured if we walked in the same direction we came, we would get to the camp. Even our own tracks are gone." "We need to stop now and figure out where in the hell we are." I took my backpack off and opened it up, searching for my map and compass. While I was busy in my backpack, I saw Pannoowau scramble for his rifle from the corner of my eye. He brought it up and fired off three rounds. I looked at him and said "What happened?" I also brought up my rifle, but noticing Pannowau's face was white as the snow on the ground. "Weendigo..." he said.

The narrator and Pannoowau make it back to camp, whereupon the narrator finally sees the Wendigo standing there at the edge of the treeline around camp: "It looked so skinny that its bones were almost pushing out of its skin. The eyes appeared so sunken, almost black, and the bony fingers were jagged like twigs. It was just standing there, watching us." 
The Wendigo, while visually frightening due to the uncanniness of its form (close enough to human but far enough to seem wrong) does nothing dangerous. It merely watches. The narrator and Pannoowau begin firing on the creature, but when the smoke clears it had vanished without a body. They run for the car, but on the journey Pannoowau is separated from the narrator unnoticed. The narrator makes it to his car and starts to drive for the main road when he sees Pannoowau in front of him. "I screamed, 'Get in the car!!' Instead of running to the passenger door, he twitched and seemed to float towards the driver's door. My instincts once again kicked in and I slammed the pedal."

The narrator makes it back to the government roads and contacts the police, telling them that his friend was hurt in a hunting accident. The story ends by informing us, "They still haven't found him."

Pannoowau is a fascinating character in this narrative. The narrator informs us, "He also lives in Alberta, but was born on a reservation. His family had taught him all the legends and customs when he was growing up, but he handles modern society well." This congratulatory nod to Pannoowau, who "handles modern society well," seems to carry a subconscious idea that natives ought not to be able to, relegating the native to an undisclosed past, coming from a reservation, a space removed within popular conception from modern spaces, his ancestry giving him some greater connection to the land. Meanwhile the narrator is part of the army, an active, voluntary agent of the colonial government. They come from two different worlds, and their alliance and eventual separation suggests an instability of this arrangement. Interestingly, the name the narrator gives to his native companion, "Pannoowau," means "he lies" in Algonquin, ${ }^{11}$ something that wouldn't be obvious to the common reader but seems to be an in-joke or subtle acknowledgement of the falseness of the story. Now, naturally that could be it, a subtle nod to the way a fictional story is being told as truth in the traditional mode of the urban legend, a tacit admission that this story is a fabrication. ${ }^{12}$ But the connection to lies and storytelling runs deeper. It is through Pannoowau that we learn that "bad spirits" are present, that the threat is a "Wendigo" that will get them killed. When they are lost, he says nothing until confronted. As they draw closer to the inevitable meeting with the Wendigo, he seems to grow stranger, more distant, more connected to the land. This is a recursion of a frequent role that native characters are relegated to, that of the noble savage. According to Shanley, "many of the 'Indian' voices most popular in mainstream America reinscribe nineteenth-century romantic images of Noble Savages" (677). These "romantic images" assuage a guilty colonial conscience. Ascribing nobility to the "savage" is what Renato Rosaldo describes as "a particular kind of nostalgia, often found under imperialism, where people mourn the passing of what they themselves have transformed" (69). This imperialist nostalgia retells the dispossession of indigenous peoples as an inevitability instead of a crime, suggesting that the conquered savage could never have survived into the modern era and couldn't help being lost to history. Stating that Pannoowau "adapts to modern society well" places him in this romanticized past. This justifies his knowledge of tracking and spirits. But in the end, Pannoowau goes Wendigo. This seems to subvert the idea of the romanticized native, an image meant to assuage a guilty conscience. The monster must be shot, unquestionably, and, if it has no right to life, it certainly has no right to territory. Colonialism is thus justified by making the native a monster that needed conquering. But it is not until this attempt to reassert colonial power occurs that the monsters come out.

\section{Notes}

11. Trumbull, Natick Dictionary

12. Other indications are present, notably the irregularity of the weather, described at $5^{\circ}$, far colder than it would be in the region in question during hunting season, as well as the nonexistence of the narrator's military regiment at the time the story took place. 
In "Territories," the protagonists don't encounter any great danger, the Wendigo being heard but unseen, an absent presence in the night, until the narrator ceases to trust Pannoowau's sense of direction and connection to the land and utilizes more modern technologies of the map and compass, both used to define space and therefore control territory. It is not until these symbols that force definition onto the land come out that the Wendigo comes out as well. The issue of colonial incursion into what was once untamed space is brought to the forefront, the intellectual conflict becoming manifested in a physical danger. However, the danger is still not quite present. Pannoowau is the only one able to perceive it at first. The narrator doesn't see it until he reaches the perceived safe space of the camp. The camp is separated from the Wendigo's space just beyond the tree line, the boundary entirely conceptual and not at all defined. The closeness of the monster has all but broken down the conceptions of territory that are a vital aspect of the colonial process, the establishment of native and non-native territories now shown to be illusory as opposed to intrinsic. The flimsiness of these boundaries shows how the real memories of colonial violence, unfiltered by imperialist nostalgia, can resurface in what Richard Terdiman calls "the pasts we carry but do not entirely cognize [that] regularly rise to colonize our present" (346). This fear of being incorporated, rather than an incorporator, contributes to the fear of the Wendigo, the narrative betraying the narrator as it allows the past to unsettle the present.

But the territorial nature of the Wendigo goes beyond physical boundaries. The colonization of the new world cannot be total until the natives are pushed out of all of their territories, both physical and cultural. Landrum explores how captured lands and objects, "[t] rophies of the Indian wars" (272), hold spiritual power, stating that "these 'vessels' of power carried the energy of the land and the people that they represented" (273). Using the example of trophies taken after the massacre at Wounded Knee, Landrum states that by holding hostage these vessels of spiritual power, "the northern plains people were both militarily and spiritually disarmed" (262). By telling stories of the Wendigo, colonial culture can attempt to reassert its ownership of the captured trophy of the Wendigo, though the repeated victory of the Wendigo in driving the narrators out of its territory suggests that this ownership is highly tenuous, history resisting redefinition. The more that colonial culture tries to mold the Wendigo into a useable shape, the more it slips away, leaving the hand trying to grasp it reshaped around its absence, and the words trying to define assert control telling stories of fear and flight.

And this brings me back to the issue of stories and who gets to tell them. The act of telling the story is an intently defining act. The words used, portrayals of characters and places, by their very nature define history or culture in some way, even unknowingly. The act of redefining something belonging to someone else is a violent act, a charge into and occupying of cultural territory. But the unsettling nature of the Wendigo prevents it from being defined by the colonizer, allowing it to slip into and out of conquered territory.

For one, the Wendigo can be seen to represent the native, portrayed as a lurking danger in the forest. The auditory difference, especially the narrator of "Cabin Fever" focusing on the sound of the speech, is noteworthy. The English language has a vast etymological family tree, deriving from both Germanic and Romantic languages, and can thus find similarity in most European language patterns, whether it be sonically or syntactically. However, languages from tribes in the Americas follow different rules and thus sound noticeably different. There are different phonemes and rules for constructing sentences and declining nouns. Most European languages decline nouns based on masculine/feminine, where many 
languages from northern America decline based on animate/inanimate. Interestingly, some words like ahsin, stone, decline as animate, suggesting an understanding of the land as having "potential for movement, for speech and volition-for personhood" (Smith and Fiore 62). The cultural differences runs so deep that even the thought behind the language is changed. The Wendigo in these tales triggers all the screen memories of the fear that plagued the colonizers of a people with uncanny faces, of a land with potential to speak.

However, another reading interprets the Wendigo as the colonizer. This is not an uncommon rhetorical device, seen in many narratives. Theresa S. Smith and Jill M. Fiore unpacks one such narrative, Linda Hogan's novel Solar Storms, wherein builders of a hydroelectric dam in once sacred ground are likened to Wendigos: "Like Windigos, the murderers of the land are gluttons who, with greed and trickery, seal their own fates in a landscape that offers no sustenance any more...they can only live by attempting to take life, both literally and figuratively, from others" (Smith and Fiore 76). In "Cabin Fever" the Wendigo is constantly in amongst the humans, taking on their forms and voices. If read assuming Wendigo-as-colonist, the meaning is clear. The Wendigo can easily assume the form of the colonist because the colonist has already become the Wendigo. This uncanny doubling unsettles both characters and reader, as it shows how flimsy the borderline between colonist and cannibal is.

The indecisive quality of the metaphor, whether it makes colonist or native into the monster, indicates the ongoing struggle over the cultural territory in which the Wendigo resides. The perpetuation of narratives often so similar that they are rapidly growing unpopular for lack of originality suggests that colonial culture is revisiting the issue over and over, the guilty colonial conscience trying to redefine its past until the monster in colonized territory is no longer in the mirror as well. Perhaps this is why posters on an anonymous board find the Wendigo so terrifying and yet so enthralling. On an anonymous board, a space without identity, a monster that can be made to look like both native and colonizer carries the weight of both identities and histories, challenging the very idea that an identity can be free of history. 


\section{$\underline{\text { WORKS CITED }}$}

Anansi. “Cabin Fever.” 4chan. 4chan, 27 Sept. 2012. Web. 6 Sept. 2013.

Boyd, Colleen, and Coll Thrush. "Introduction: Bringing Ghosts to Ground." Phantom Past, Indigenous Presence. Ed. Colleen E. Boyd and Coll Thrush. Lincoln: University of Nebraska Press, 2011. vii-xl. Print.

Delerth, August. "Ithaqua." The Ithaqua Cycle: The Wind-Walker of the Icy Wastes. Ed. Robert M. Price. Oakland, CA: Chaosium, 1998. n.p. Print.

Erdrich, Louise. Tracks: A Novel. New York: Henry Holt, 1988. Print.

Mackenthun, Gesa. "Haunted Real Estate: The Occlusion of Colonial Dispossession and Signatures of Cultural Survival in U.S. Horror Fiction." Amerikastudien / American Studies: Media and Cultural Memory 43.1 (1998): 93-108. Print.

Gordon, Avery. Ghostly Matters: Haunting and the Sociological Imagination. Minneapolis: University of Minneapolis Press, 1997. Print.

Hogan, Linda. Solar Storms: A Novel. New York: Scribner, 1995. Print.

Keenan, Deirdre. "Trespassing Native Ground: American Indian Studies and Problems of Non-Native Work.” The Journal of the Midwest Modern Language Association, 34.1 (Autumn, 2000 - Winter, 2001): 179-89. Print.

King, Stephen. Pet Semetary. New York: Doubleday, 1983. Print.

Landrum, Cynthia. "Shape-shifters, Ghosts, and Residual Power: An examination of Northern Plans Spiritual Beliefs, Location, Objects, and Spiritual Colonialism." Phantom Past, Indigenous Presence. Ed. Colleen E. Boyd and Coll Thrush. Lincoln: University of Nebraska Press, 2011. 255-279. Print.

Le Jeune, Paul. "A Sort of Werewolf." Windigo: An Anthology of Fact and Fantastic Fiction. Ed. John Robert Colombo. Lincoln: University of Nebraska Press, 1982. 7. Print.

Norman, Howard A. Where the Chill Came From: Cree Wendigo Tales and Journeys. San Francisco: North Point Press, 1982. Print

Rosaldo, Renato. Culture \& Truth: The Remaking of Social Analysis. Boston: Beacon Press, 1993. Print. 


\section{$\underline{\text { WORKS CITED }}$}

Smith, Theresa S. and Jill M. Fiore. "Landscape as Narrative, Narrative as Landscape." Studies in American Indian Literatures, 22.4 (Winter 2010): 58-61. Print.

Shanley, Kathryn W. "The Indians America Loves to Love and Read: American Indian Identify and Cultural Appropriation.” American Indian Quarterly, 21.4 (Autumn, 1997): 675-702. Print.

Terdiman, Richard. Present Past: Modernity and Memory Crisis. Ithaca: Cornell University Press, 1993. Print.

“Territories.” 4chan. 4chan, 23 July 2013. Web. 6 Sept. 2013.

Trumbull, J. Hammond. Natick Dictionary. Washington: Government Printing Office 1903. Print.

Turner, D. H. "Windigo Mythology and the Analysis of Cree Social Structure." Athropologica 19.1 (1977): 63-73. Print. 